Research Article

Open Access

\title{
Optimization of Enzymatic Protein Hydrolysis conditions to obtain maximum Angiotensin-I- Converting Enzyme (ACE) inhibitory activity from Angel Wing Clam (Pholas orientalis) Meat
}

\author{
Amiza Binti Mat Amin*, HA Liyana and Zaliha Harun \\ School of Food Science and Technology, Universiti Malaysia Terengganu, 21030 Kuala Terengganu, Terengganu, Malaysia
}

\section{Article Info}

*Corresponding author:
Amiza Binti Mat Amin
School of Food Science and Technology
Universiti Malaysia Terengganu
21030 Kuala Terengganu
Malaysia
E-mail: ama@umt.edu.my

Received: October 24, 2016

Accepted: November 16, 2016

Published: March 17, 2017

Citation: Amin AM, Liyana HA, Harun Z. Optimization of Enzymatic Protein Hydrolysis conditions to obtain maximum AngiotensinI-Converting Enzyme (ACE) inhibitory activity from Angel Wing Clam (Pholas orientalis) Meat. Madridge J Food Technol. 2017; 2(1): 64-72.

doi: $10.18689 / \mathrm{mjft}-1000110$

\section{Copyright: (c) 2017 The Author(s). This work is licensed under a Creative Commons Attribution 4.0 International License, which permits unrestricted use, distribution, and reproduction in any medium, provided the original work is properly cited.}

Published by Madridge Publishers

\begin{abstract}
Optimization of enzymatic protein hydrolysis conditions of angel wing clam (Pholas orientalis) meat to yield maximum angiotensin I-converting enzyme inhibitory (ACE inhibitory) activity was carried out using Response Surface Methodology (RSM). Protein content in angel wing clam meat was $9.04 \pm 0.06 \%$. To determine food grade enzyme and range of hydrolysis time to be used in optimization study, screening study was carried out. Four commercial food grade enzymes (Alcalase ${ }^{\circledR}$, Protamex $^{\mathrm{TM}}$, Neutrase ${ }^{\circledR}$ and papain) at 2 and 4 hours hydrolysis time were used to yield the highest ACE inhibitory activity. A further screening study were done on Alcalase ${ }^{\circledR}$ and papain at 1 hour hydrolysis time. It was found that Alcalase ${ }^{\circledR}(75.86 \% \pm 2.64)$ and papain $(77.13 \% \pm$ 2.63) at 1 hour hydrolysis time exhibited the highest ACE inhibitory activity. However, Alcalase ${ }^{\circledR}$ was chosen for the hydrolysis in the optimization study. Four protein hydrolysis parameters including temperature $\left(50^{\circ} \mathrm{C}-60^{\circ} \mathrm{C}\right), \mathrm{pH}(6.5-8.5)$, hydrolysis time $(30$ minutes - 90 minutes) and enzyme to substrate $(E / S)$ ratio $(1.0 \%-2.0 \%)$ were employed at three level using a face-centered central composite design (CCD) by using RSM. The enzymatic hydrolysis of angel wing clam meat towards ACE inhibitory activity can be predicted by using quadratic model. The optimum hydrolysis conditions to yield maximum ACE inhibitory activity was at $54.8^{\circ} \mathrm{C}, \mathrm{pH}$ of $7.7,33$ minutes of hydrolysis time and $\mathrm{E} / \mathrm{S}$ ratio of $1.0 \%$. It was found that the predicted value of ACE inhibitory activity (85.21\%) was close to the experimental value (85.64\%). This study shows that RSM can be applied successfully to describe interrelationship between hydrolysis conditions and ACE inhibitory activity. On the other hand, the half maximal inhibitory concentration $\left(\mathrm{IC}_{50}\right)$ value for angel wing clam meat hydrolysate prepared under optimum condition was $3.63 \mathrm{mg} / \mathrm{ml} \pm 0.48$.
\end{abstract}

Keywords: Angiotensin-I-converting enzyme (ACE); Inhibitory; Hydrolysis; Optimization; Angelwing clam.

\section{Introduction}

Protein hydrolysis is widely used in food industry to modify physiochemical properties of protein, improve nutritional quality of protein and produce bioactive peptides [1]. Protein hydrolysis involves the cleavage of the peptides bonds and breakdown of protein into amino acids and peptides by using acid, alkali or enzyme [2,3]. Enzymatic protein hydrolysis using commercial food grade enzymes are more desirable and consistent due to the better control in term of hydrolysates properties [4]. Bioactive peptides are small protein fragments that may give benefits to human's health [5]. 
Angiotensin-I converting enzyme (ACE) plays an important role in the regulation of blood pressure $[6,7]$. ACE catalyzes the conversion of inactive angiotensin-I into a potent vasoconstrictor, angotensin-II [6] which leads to hypertension. Antihypertensive drug such as captopril and enalapril are widely used in hypertension treatment and other cardio-related diseases [8]. However, these synthetic antihypertensive drugs may cause several adverse secondary effects. Therefore, search for safer ACE inhibitors as alternatives to synthetic drugs is of great interest among researchers and many natural and safe ACE inhibitory peptides have been isolated from functional food and natural bio-resources $[9,10]$. ACE inhibitors with maximum inhibitory activities can be obtained through the optimization of protein hydrolysis conditions. Response Surface Methodology is a commonly used tool to optimize chemical process conditions to obtain desired responses whereby the mathematical model generated could explain the relationship between the variables and the responses [11].

Anglewing clam is a bivalve mollusc found mostly in the tidal flats of Southeast Asia [12]. Angelwing clam is very rich in protein [13]. Hence, it has the potential to be the substrate to prepare ACE inhibitory peptides. Normah and Nurul Fasihah [14] have reported on the physicochemical properties and bitterness of angelwing clam hydrolysate hydrolyzed using $3 \%$ bromelain for $2 \mathrm{hrs}$. They reported that the resulting hydrolysate with degree of hydrolysis of $12.57 \%$ gave bitter taste. To date, no study has been reported on the optimization of ACE inhibitory activity from angelwing clam (Pholas orientalis). The objectives of this study were to determine the effect of different types of commercial food grade enzymes and hydrolysis time on the ACE inhibitory activity of angelwing clam meat, to optimize the enzymatic protein hydrolysis conditions ( $\mathrm{pH}$, temperature, time and enzyme concentration) with maximum ACE inhibitory activity from angelwing clam meat and finally to determine the half maximal inhibitory concentration $\left(\mathrm{IC}_{50}\right)$ of ACE inhibitory from angelwing clam meat hydrolysate prepared at optimum conditions.

\section{Main Body/Methods}

\section{Raw material}

Twenty kilograms of whole fresh angelwing clam was purchased from a supplier in Sekinchan, Kuala Selangor, Malaysia and transported in ice to the laboratory. The clams were pried open with knife to obtain its flesh, cleaned and washed for several times to remove any contaminants. A total of $4.6 \mathrm{~kg}$ of angelwing clam meat obtained from $20 \mathrm{~kg}$ of whole angelwing clams was homogenized using a food processor and packed in plastic bags and stored at $-20^{\circ} \mathrm{C}$. Determination of protein content of the homogenized angelwing clam meat was done using Kjeldahl method according to AOAC [15].

\section{Chemicals and reagents}

The commercial food grade enzymes used (Alcalase ${ }^{\circledR}$, Neutrase ${ }^{\circledR}$, Protamex ${ }^{\top \mathrm{M}}$ and papain), Angiotensin-I-converting enzyme (ACE) and Hipurry-L-histidyl-L-leucine $(\mathrm{HHL})$ were purchased from Sigma-Aldrich (M) Sdn. Bhd. Other chemicals used were of analytical grades.

\section{Preparation of lyophilized angelwing clam meat hydrolysate}

Hydrolysis mixture of anglewing clam flesh, enzyme and water was prepared according to AOAC [15]. The mixture was heated at $85^{\circ} \mathrm{C}$ for 20 minutes in a water bath (TE-10D Temp., Techne, UK) to deactivate the endogenous enzymes. Method of Ko et al. [16] with some modification, were employed in the enzymatic hydrolysis of anglewing clam. $\mathrm{pH}$ of the hydrolysis was adjusted according to table 1 by $1.0 \mathrm{M} \mathrm{NaOH}$ using a pH meter (InoLab pH 720, Wissenschaftlich-Technische Werkstatten $\mathrm{GmbH}$, Germany) while water bath shaker (Shaker Bath 903, Protech, UK) was used to adjust the temperature. Enzymatic hydrolysis was started by addition of the enzyme into hydrolysis mixture. Once the hydrolysis completed, the mixture was heated at $85^{\circ} \mathrm{C}$ for 20 minutes in a water bath to inactivate the proteinase activity. The cooled protein hydrolysate was centrifuged at $10,000 \mathrm{rpm}$ (at $4^{\circ} \mathrm{C}$ for 5 minutes). The resulting supernatant was then frozen, prior freezed drying. The lyophilized angelwing clam meat hydrolysate was kept in airtight container for further ACE inhibitory assay [17].

Table 1. Enzymatic protein hydrolysis conditions for screening of commercial food grade enzymes

\begin{tabular}{|c|c|c|c|}
\hline Enzyme & $\mathrm{pH}$ & Temperature $\left({ }^{\circ} \mathrm{C}\right)$ & Hydrolysis time (hour) \\
\hline Alcalase ${ }^{\circledR}$ & 8.5 & 55 & 2,4 \\
\hline Protamex ${ }^{\top M}$ & 6.5 & 50 & 2,4 \\
\hline Neutrase ${ }^{\circledR}$ & 7 & 55 & 2,4 \\
\hline Papain & 6 & 60 & 2,4 \\
\hline
\end{tabular}

Screening of four commercial food grade proteinases (Alcalase ${ }^{\circledR}$, Protamex ${ }^{\top \mathrm{T}}$, Neutrase $^{\circledR}$ and papain) was carried out to determine the proteinase that gave the highest ACE inhibitory activity from angelwing clam meat hydrolysis. The enzyme concentration was fixed to $1 \%$, while hydrolysis was completed in 2 and 4 hours of hydrolysis time.

\section{Determination of in-vitro ACE inhibitory activity}

ACE inhibitory activity was determined using spectrophotometric assay according to Cushman and Cheung [18]. It was based on the hydrolysis of hippuryl-L-histidyl-Lleucine $(\mathrm{HHL})$ by ACE to hippuric acid $(\mathrm{HA})$ and histidyl-leucine $(\mathrm{HL})$ as products. Hippuric acid measurement was carried out at $228 \mathrm{~nm}$.

Firstly, $50 \mu \mathrm{l}$ buffer of angelwing clam meat protein hydrolysate sample $(1 \mathrm{mg} / \mathrm{ml})$ and $50 \mu \mathrm{l}$ of ACE solution (2 $\mathrm{mU} / \mathrm{ml}$ ) were pre-incubated at $37^{\circ} \mathrm{C}$ for 10 minutes by using a water bath (Shaker bath 903, Protech, UK). Then, the hydrolysate was incubated with $150 \mu \mathrm{l}$ of the substrate ( $2.17 \mathrm{mM} \mathrm{HHL}$ in $0.1 \mathrm{M}$ sodium borate buffer containing $0.3 \mathrm{M}$ $\mathrm{NaCl}$ at $\mathrm{pH} 8.3$ ) at $37^{\circ} \mathrm{C}$ for 30 minutes. Lastly, $250 \mu \mathrm{l}$ of $1 \mathrm{M}$ $\mathrm{HCl}$ was added to stop the reaction. The resulting $\mathrm{HA}$ was extracted with $500 \mu \mathrm{l}$ of ethyl acetate. The aliquot $(200 \mu \mathrm{l})$ of the extract was evaporated in a dry oven (UNB 400, Memmert, Germany) at $80^{\circ} \mathrm{C}$ for 30 minutes. Completely dried HA 
formed a white ring precipitate at the bottom of the container. The residue was then dissolved in $1 \mathrm{ml}$ distilled water and its absorbance was measured at $288 \mathrm{~nm}$ using UV-Visible spectrophotometer (Gary 50 Probe, Varian Inc., USA).

The ACE inhibitory activity was calculated by using the following formula:

inhibition (\%) $=A_{c}-A_{s} / A_{c}-A_{b}$

Where,

$A_{c}=$ Absorbance of control sample $(H H L+$ buffer $+A C E)$

$A_{S}=$ Absorbance of sample solution $(\mathrm{HHL}+$ sample $+\mathrm{ACE})$

$A_{b}=$ Absorbance of blank solution (HHL + buffer)

\section{Optimization of enzymatic protein hydrolysis to obtain maximum ACE inhibitory activity}

Optimization of enzymatic hydrolysis was done using Response Surface Methodology (RSM) with a face-centered Central Composite Design (CCD) to optimize the hydrolysis conditions including $\mathrm{pH}$, temperature, hydrolysis time and enzyme to substrate concentration ratio (\% w/w). The design was employed at three equidistant levels (Table 2) which generated 30 experimental runs with 6 central points [19].

Table 2. Experimental range and values of the independent variables adopted at three equidistant levels

\begin{tabular}{|l|l|l|l|l|}
\hline Independent variables & Symbol & \multicolumn{3}{l|}{ Range and levels } \\
\hline & & -1 & 0 & +1 \\
\hline $\mathrm{pH}$ & $\mathrm{X}_{1}$ & 6.5 & 7.5 & 8.5 \\
\hline Temperature $\left({ }^{\circ} \mathrm{C}\right)$ & $\mathrm{X}_{2}$ & 50 & 55 & 60 \\
\hline Hydrolysis time (minutes) & $\mathrm{X}_{3}$ & 30 & 60 & 90 \\
\hline Enzyme concentration $(\mathrm{E} / \mathrm{S}, \% \mathrm{w} / \mathrm{w})$ & $\mathrm{X}_{4}$ & 1.0 & 1.5 & 2.0 \\
\hline
\end{tabular}

\section{Validation of optimum condition}

Validation was carried out to check the validity of the predicted value suggested from RSM. The hydrolysis of angelwing clam meat at optimum condition suggested was carried out in quadruplicates. The lyophilized hydrolysate from each replicate was analyzed for ACE inhibitory activity. The mean of experimental values was then compared with predicted value using one sample t-test.

\section{Determination of half maximal inhibitory concentration (IC $\left.\mathrm{C}_{50}\right)$ of angelwing clam hydrolysate prepared at optimum conditions}

Half maximal inhibitory concentration or $\mathrm{IC}_{50}$ is defined as the inhibitor's concentration needed to inhibit $50 \%$ of the activity of ACE [18]. IC 50 of angelwing clam meat hydrolysate prepared at optimum condition was analyzed for its ACE inhibitory determination. Serial dilutions of angelwing clam meat hydrolysate used were 2, 4, 6, 8 and $10 \mathrm{mg} / \mathrm{ml}$. A graph of ACE inhibitory versus concentration of angelwing clam meat hydrolysate was plotted to determine the $\mathrm{IC}_{50}$.

\section{Statistical analysis}

For screening study, one-way ANOVA was used to compare the ACE inhibitory activity between commercial food grade proteinases and hydrolysis time. For optimization study, the data was analyzed using Design Expert 6.0.10 software (Stat-Ease Inc, USA). The data was subjected to statistical analysis of variance (ANOVA). The important analysis included sequential model sum of squares, ANOVA, final equation and suggested solutions for optimization were given by the software. For validation study, one-sample t-test was used to compare the closeness between the predicted ACE inhibitory value and the experimental ACE inhibitory value.

\section{Results and Discussion}

\section{Yield and protein content of angelwing clam meat}

Protein content of raw angelwing clam meat was $9.04 \pm$ $0.06 \%$ and it is lower compared to angelwing clam flesh reported by Normah and Nurfazlika (13.72 \pm 0.56\%) [13] Normah and Nurul Fasihah (25.91 $0.56 \%$ ) [14]. The difference in protein content is due to the difference in protein content method. This study used Kjeldahl method, while Normah and Nurul Fasihah [14] used Lowry method. Besides, the protein content of angelwing clam may vary due to the differences in habitat of angelwing clam sample obtained, the feed intake and sexual changes in connection with spawning [20].

\section{Screening of commercial food grade enzymes and hydrolysis time}

The objective of screening was to identify the most suitable enzyme in producing the highest ACE inhibitory activity. Figure 1 shows that there is no difference of ACE activity of hydrolysate from different enzymes. However, hydrolysate from papain and Alcalase ${ }^{\circledR}$ enzymatic hydrolysate gave higher ACE inhibitory activity compared to other enzymes. Further screeening was carried out to check whether 1 hour of hydrolysis using papain and Alcalase ${ }^{\circledR}$ will produce higher or lower level ACE inhibitory activity, compared to 2 and 4 hours of hydrolysis. Figure 2 shows the ACE inhibitory activity of Alcalase ${ }^{\circledR}$ and papain hydrolysis in which 1 hour hydrolysis time gave higher ACE inhibitory activity compared to 2 and 4 hours, for both proteinases $(p<0.05)$. In addition, 1 hour of papain hydrolysis $(77.13 \% \pm 2.63 \%)$ gave higher ACE inhibitory activity compared to Alcalase ${ }^{\circledR}(75.88 \% \pm 2.64)$, but there was no significant different $(p<0.05)$. Alcalase ${ }^{\circledR}$ was chosen for optimization study to obtain maximum ACE inhibitory activity from angelwing clam meat, because Alcalase ${ }^{\circledR}$ is more economical than papain and it is originated from microbial sources [21]. Based on the result in figure 2, the suitable range of hydrolysis time is between 1-2 hours.

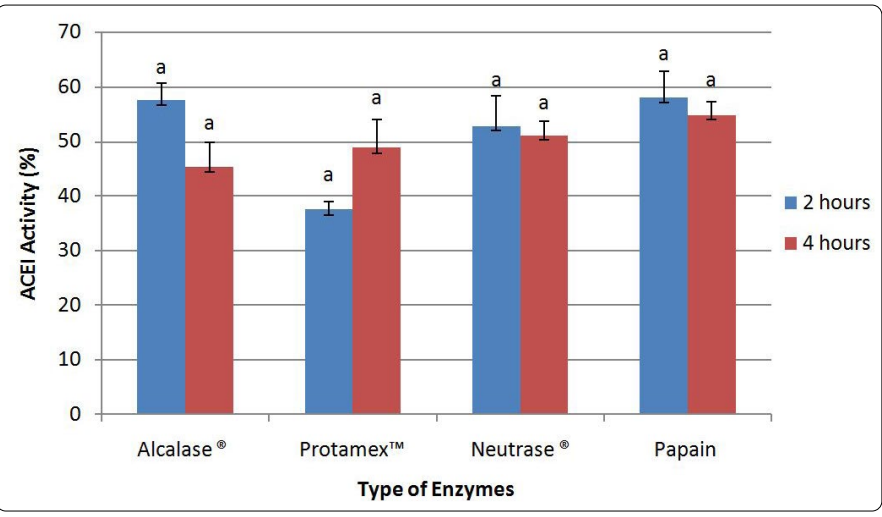

Figure 1. ACE inhibitory activity of angelwing clam meat hydrolysates prepared using different commercial food grade enzymes at 2 and 4 hours hydrolysis time. 


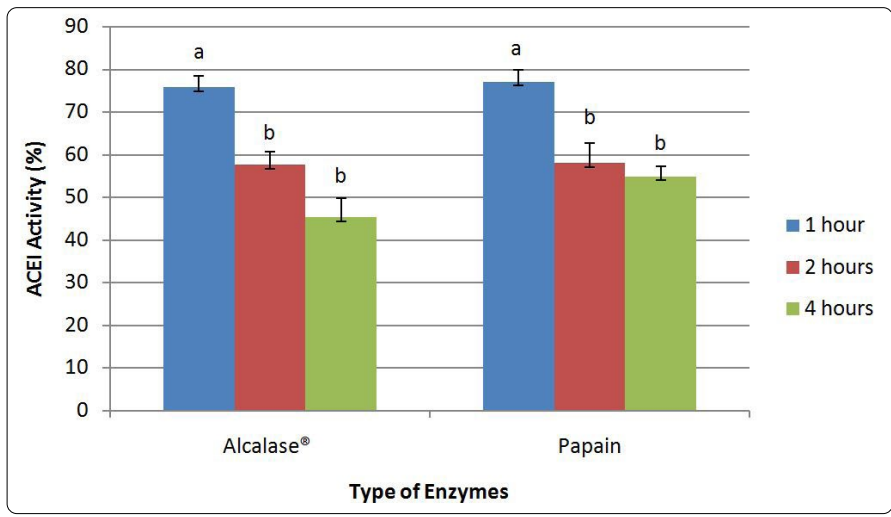

Figure 2. ACE inhibitory activity of angelwing clam meat hydrolysate prepared using Alcalase ${ }^{\circledR}$ and papain at 1, 2 and 4 hours hydrolysis time.

Previous studies have reported that hydrolysate from food proteins hydrolyzed using Alcalase ${ }^{\circledR}$ had shown potent ACE inhibitory activities such as hydrolysates of salmon by product [21] blood cockle [11], dark muscle tuna by product [22], seaweed [23,24] and squid gelatine [8]. This suggests that Alcalase ${ }^{\circledR}$ dominated most of the enzymatic protein hydrolysis. According to Qu et al. [24], the pH values used for enzymatic hydrolysis for Alcalase ${ }^{\circledR}$ was in alkaline condition whereas for Protamex ${ }^{\mathrm{TM}}$, Neutrase ${ }^{\circledR}$ and papain were near acidic or neutral condition. Alcalase ${ }^{\circledR}$ aided protein hydrolysis with a high degree in a short duration, under moderate $\mathrm{pH}$ conditions as compared to neutral or acidic enzyme [24-26]. Furthermore, Alcalase ${ }^{\circledR}$ was able to produce shorter peptides sequences and terminal amino acid sequences [27].

\section{Optimization of enzymatic protein hydrolysis conditions of angelwing clam meat to obtain maximum ACE inhibitory activity using Alcalase ${ }^{\circledR}$}

Response Surface Methodology (RSM) was employed to optimize the enzymatic protein hydrolysis of angelwing clam meat using Alcalase ${ }^{\circledR}$ to obtain maximum ACE inhibitory activity. Design Expert 6.0.10 software generated the experimental design and analyzed the experimental data collected. Table 3 shows the data of ACE inhibitory activity obtained from 30 runs of enzymatic protein hydrolysis. The range of ACE inhibitory activity obtained was from $54.6 \%$ to $85.17 \%$. Based on the data, the highest ACE inhibitory activity was obtained with hydrolysis at temperature of $55^{\circ} \mathrm{C}, \mathrm{pH} 7.5$, hydrolysis time of 60 minutes and $1.5 \%$ of enzyme concentration.

The range of ACE inhibitory activity obtained in this study was higher compared to previous studies such as sardinella by product with ACE inhibitory activity range of $13.2 \%$ to $63.2 \%$ [28] whey protein with range of $53.4 \%$ to $73.45 \%$ [29] and milk protein with range of $22.4 \%$ to $79.7 \%$ [30]. However, the range of ACE inhibitory activity in this study is comparable to those of round scad processing waste (55.26-90.78\%) and edible bird's nest (55.54-88.86\%) (unpublished data). The difference in value of ACE inhibitory activity obtained from different protein source may due to different types of source of protein, different range of parameters used and different type of enzymes used during hydrolysis process.
Table 3. Experimental data of ACE inhibitory activity (\%) from angelwing clam meat hydrolysate using face-centered Central Composite Design (CCD)

\begin{tabular}{|c|c|c|c|c|c|c|}
\hline & & Factor 1 & Factor 2 & Factor 3 & Factor 4 & Response 1 \\
\hline Std & Run & $\begin{array}{c}\mathrm{A}: \\
\text { Temperature } \\
\left({ }^{\circ} \mathrm{C}\right)\end{array}$ & $\mathrm{B}: \mathrm{pH}$ & $\begin{array}{c}\text { C: } \\
\text { Hydrolysis } \\
\text { time } \\
\text { (minutes) }\end{array}$ & $\begin{array}{l}\text { D: Enzyme } \\
\text { concentration } \\
(\%)\end{array}$ & $\begin{array}{c}\text { ACE } \\
\text { inhibitory } \\
\text { activity (\%) }\end{array}$ \\
\hline 13 & 1 & 50.0 & 6.5 & 90 & 2.0 & 64.60 \\
\hline 4 & 2 & 60.0 & 8.5 & 30 & 1.0 & 70.00 \\
\hline 18 & 3 & 60.0 & 7.5 & 60 & 1.5 & 61.76 \\
\hline 16 & 4 & 60.0 & 8.5 & 90 & 2.0 & 60.04 \\
\hline 24 & 5 & 55.0 & 7.5 & 60 & 2.0 & 82.81 \\
\hline 7 & 6 & 50.0 & 8.5 & 90 & 1.0 & 69.30 \\
\hline 15 & 7 & 50.0 & 8.5 & 90 & 2.0 & 61.29 \\
\hline 29 & 8 & 55.0 & 7.5 & 60 & 1.5 & 84.54 \\
\hline 14 & 9 & 60.0 & 6.5 & 90 & 2.0 & 60.69 \\
\hline 11 & 10 & 50.0 & 8.5 & 30 & 2.0 & 67.20 \\
\hline 2 & 11 & 60.0 & 6.5 & 30 & 1.0 & 56.80 \\
\hline 28 & 12 & 55.0 & 7.5 & 60 & 1.5 & 85.17 \\
\hline 1 & 13 & 50.0 & 6.5 & 30 & 1.0 & 62.87 \\
\hline 10 & 14 & 60.0 & 6.5 & 30 & 2.0 & 54.6 \\
\hline 26 & 15 & 55.0 & 7.5 & 60 & 1.5 & 77.76 \\
\hline 3 & 16 & 50.0 & 8.5 & 30 & 1.0 & 67.10 \\
\hline 5 & 17 & 50.0 & 6.5 & 90 & 1.0 & 70.77 \\
\hline 8 & 18 & 60.0 & 8.5 & 90 & 1.0 & 70.04 \\
\hline 25 & 19 & 55.0 & 7.5 & 60 & 1.5 & 82.81 \\
\hline 22 & 20 & 55.0 & 7.5 & 90 & 1.5 & 79.97 \\
\hline 6 & 21 & 60.0 & 6.5 & 90 & 1.0 & 64.34 \\
\hline 27 & 22 & 55.0 & 7.5 & 60 & 1.5 & 82.43 \\
\hline 17 & 23 & 50.0 & 7.5 & 60 & 1.5 & 69.66 \\
\hline 9 & 24 & 50.0 & 6.5 & 30 & 2.0 & 69.12 \\
\hline 30 & 25 & 55.0 & 7.5 & 60 & 1.5 & 80.08 \\
\hline 20 & 26 & 55.0 & 8.5 & 60 & 1.5 & 73.3 \\
\hline 21 & 27 & 55.0 & 7.5 & 30 & 1.5 & 82.49 \\
\hline 19 & 28 & 55.0 & 6.5 & 60 & 1.5 & 72.92 \\
\hline 23 & 29 & 55.0 & 7.5 & 60 & 1.0 & 84.70 \\
\hline 12 & 30 & 60.0 & 8.5 & 30 & 2.0 & 71.92 \\
\hline
\end{tabular}

The optimization data of 30 runs were further analyzed through model adequacy checking to examine whether the fitted model can provides an adequate approximation to the true system. Data was analyzed for its analysis of variance (ANOVA), coefficient variation, diagnostic case statistics and response surface plots and effect of factors. The prediction model for the response variable could be fitted into linear, two-factor interaction (2FI), quadratic or cubic. Table 4 shows the suggested model for ACE inhibitory activity of angelwing clam meat hydrolysate. The model equation suggested was quadratic as it posses low standard deviation, high R-squared values and low PRESS value. The standard deviation for the selected model was 2.81 which was the lowest among all models while the R-Squared value for the selected model was 0.9506 which indicated that $95.06 \%$ of the variability in the response on ACE inhibitory activity. Although cubic model showed highest R-squared value, but because it was an aliased model, thus it could not be appropriate and useful model. According to Myers et al. [31] the adjusted R-Squared value is a variation of $R$-Squared value that reflects the number of factors in the model. Therefore, the adjusted $\mathrm{R}$-Squared value is more preferable closer to 1 but it is usually lower that R-squared value. On the other hands, Prediction Error Sum of Square (PRESS) measures the goodness of the 
model for the experiment which likely to predict the responses in new experiment [31]. PRESS statistic predicted the residual error sum of square to show how well the model fits the data and smaller the PRESS is preferable [31].

\begin{tabular}{|c|c|c|c|c|c|c|}
\hline Table 4. Model Summary Statistics for ACE inhibitory activity \\
\hline Source & Std. Dev. & R-Squared & $\begin{array}{c}\text { Adjusted } \\
\text { R-Squared }\end{array}$ & $\begin{array}{c}\text { Predicted } \\
\text { R-Squared }\end{array}$ & PRESS & \\
\hline Linear & 9.48 & 0.0623 & -0.0877 & -0.3194 & 3160.88 & \\
\hline 2 FI & 10.28 & 0.1615 & -0.2798 & -1.7197 & 6515.66 & \\
\hline Quadratic & $\underline{2.81}$ & $\underline{0.9506}$ & $\underline{0.9046}$ & $\underline{0.7721}$ & $\underline{545.96}$ & Suggested \\
\hline Cubic & 3.14 & 0.9712 & 0.8808 & -1.2402 & 5366.87 & Aliased \\
\hline
\end{tabular}

Most studies on optimization of ACE inhibitory activity can be fitted using quadratic model such as for pacific hake [32], goldstripe sardine [33], fish protein hydrolysate from underutilized fish Pellona ditchela [34] tilapia scale gelatine [35], shrimp waste [36] and water-soluble fish [37]. Analysis of variance (ANOVA) statistically evaluated the suggested model to demonstrate which variable would give a significant effect on ACE inhibitory activity. ANOVA was used to evaluate the quality of the model fitted where comparison between the variation between the treatment and the random errors inherent to the measurement of the responses. Table 5 shows the ANOVA for the response surface quadratic model after model reduction. Based on the results, the F-value of the model was 32.74, which indicated that the model was significant with a probability of $0.01 \%$ chance that this large $F$-value could occur due to noise. The Prob $>F$ value with less than 0.05 implied that the model was significant. Thus, in this study, $A, B, A^{2}, B^{2}, D^{2}, A B, B C$ and $C D$ were significant model terms. Meanwhile, the Prob $>\mathrm{F}$ value with more 0.05 is not significant model terms and needs to be excluded in order to improve the fitness of the model.

Table 5. ANOVA table for Response Surface Quadratic Model for ACE inhibitory activity after model reduction

\begin{tabular}{lllllll}
\hline Source & $\begin{array}{l}\text { Sum of } \\
\text { Squares }\end{array}$ & DF & $\begin{array}{l}\text { Mean } \\
\text { Square }\end{array}$ & F Value & Prob $>$ F & \\
\hline Model & 2264.31 & 10 & 226.43 & 32.74 & $<0.0001$ & Significant \\
A & 55.90 & 1 & 55.90 & 8.08 & 0.0104 & \\
$B$ & 62.27 & 1 & 62.27 & 9.01 & 0.0073 & \\
C & 0.062 & 1 & 0.062 & $9.027 E-$ & 0.9253 & \\
D & 31.07 & 1 & 31.07 & 4.49 & 0.0474 & \\
$A^{2}$ & 549.46 & 1 & 549.46 & 79.46 & $<0.0001$ & \\
$B^{2}$ & 120.40 & 1 & 120.40 & 17.41 & 0.0005 & \\
$D^{2}$ & 48.48 & 1 & 48.48 & 7.01 & 0.0159 & \\
AB & 90.44 & 1 & 90.44 & 13.08 & 0.0018 & \\
BC & 66.26 & 1 & 66.26 & 9.58 & 0.0060 & \\
CD & 71.83 & 1 & 71.83 & 10.39 & 0.0045 & \\
Residual & 131.39 & 19 & 6.92 & & & not \\
Lack of Fit & 92.49 & 14 & 6.61 & 0.85 & 0.6317 & significant \\
Pure Error & 38.90 & 5 & 7.78 & & & \\
Cor Total & 2395.70 & 29 & & & & \\
\hline
\end{tabular}

The"Lack of Fit" test was used to evaluate the fitness of the model. The lack of fit test should be insignificant as significant of the lack of fit implied that the regressorresponse relationship are not accounted by the mode [38]. Based on table 5, the "Lack of Fit F-value" was 0.85 which indicated not significant relative to pure error with $63.17 \%$ of chance that a "Lack of Fit F-value" could occur due to noise.

Adjusted R-Squared is the number of terms in the model relative to the number of points in the design. Meanwhile, predicted R-Squared is used to estimate the amount the amount of variation in new data explained by the model. Based on table 6 , the value of R-Squared was 0.9452 . The value of "Pred R-Squared" (0.8563) was close to "Adj R-Squared" value (0.9163). The difference between both values was 0.06 . Montgomery [31] suggested that the difference between Predicted R-Squared and Adjusted $\mathrm{R}$-Squared should be less than 0.2 , as greater value indicates there are some problems with the model. Hence, the difference of the value between "Pred R-Squared" and "Adj R-Squared" was acceptable. On the other hands, "Adeq Precision" measures the signal to noise ratio [39]. A ratio that is greater than 4 is desirable. Thus, this model can be used to navigate the design space as the ratio (19.16) was desirable produced adequate signal.

Table 6. Summary statistics of reduced model for ACE inhibitory activity

\begin{tabular}{llll}
\hline Std. Dev. & 2.63 & R-Squared & 0.9452 \\
Mean & 71.37 & Adj R-Squared & 0.9163 \\
C. V. & 3.68 & Pred R-Squared & 0.8563 \\
PRESS & 344.24 & Adeq Precisison & 19.166 \\
\hline
\end{tabular}

From the model, the final equation in terms of coded factors was as follows:

ACE inhibitory activity $=+81.15-1.76^{*} \mathrm{~A}+1.86^{*} \mathrm{~B}-0.059^{*} \mathrm{C}-$ $1.31^{\star} D-13.91^{\star} A^{2}-6.51^{*} B^{2}+4.13^{*} D^{2}+2.38^{*} A * B-2.03^{*} B^{*} C-$ $2.12^{*} C^{*} \mathrm{D}$

The final equation in terms of actual factors as following:

ACE inhibitory activity $=-1769.02411+57.29681^{*} \mathrm{~A}+$ $77.46670 * B+0.71866{ }^{*} C-43.74141 * D-0.55650 * A^{2}-$ $6.51261^{*} B^{2}+16.52955^{*} D^{2}+0.47550^{*} A * B-0.067833^{*} B{ }^{*} C-$ $0.14125^{*} C^{*} \mathrm{D}$

Where A represents temperature, $\mathrm{B}$ represents $\mathrm{pH}, \mathrm{C}$ represents hydrolysis time and $D$ represents enzyme concentration.

The equation shows that the most influential factor for angelwing clam meat hydrolysis to onbtain maximum ACE inhibitory activity were $\mathrm{pH}$ followed by temperature, hydrolysis time and enzyme concentration. This equation could be used to predict and control angelwing clam meat hydrolysis using Alcalase ${ }^{\circledR}$.

\section{Response surface plots and the effects of factors for ACE inhibitory activity response}

Three-dimensional response surface graphs were presented to illustrate the interactive effects of the independent variables on ACE inhibitory activity and to determine the optimum level of each variable for maximum response. Figure 3 shows the response surface plot with interaction between temperature and $\mathrm{pH}$. The result shows the response surface curve had a bell shaped graph with a maximum point in the moderate range of independent variables, for both $\mathrm{pH}$ and temperature. According to Aspmo et al. [25]. The optimum pH range for Alcalase ${ }^{\circledR}$ to function was from $\mathrm{pH} 6$ to $\mathrm{pH}$ 10. $\mathrm{pH}$ could affect both the substrate and enzyme by changing the distribution and confirmation of 
the molecules at very acidic or alkaline condition. However, at very high $\mathrm{pH}$, the enzymes tend to undergo irreversible denaturation and loss of stability [40,41]. After optimum condition was reached, the ACE inhibitory activity dropped. According to Nelson [41], the protein structure of enzymes might denature and influence the proteolytic activity if the hydrolysis is kept at higher temperature.

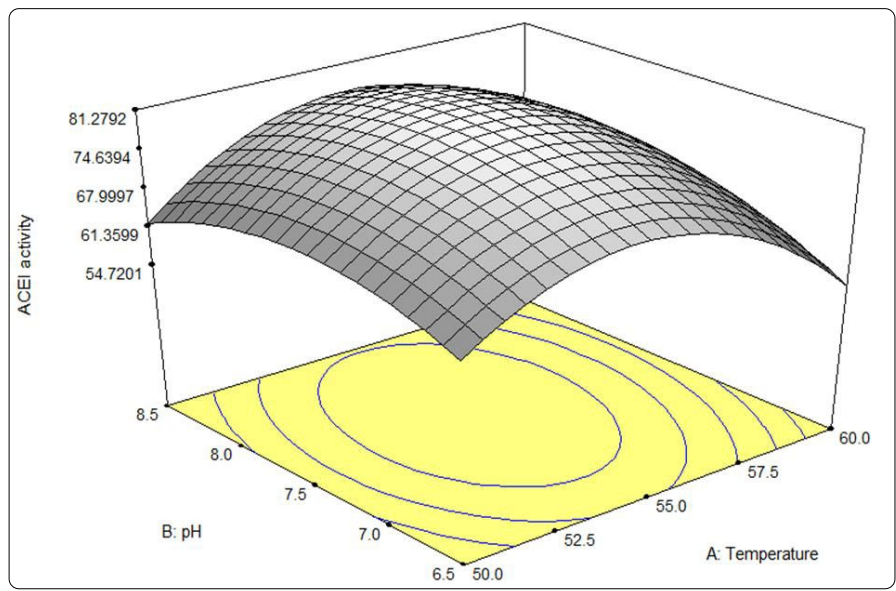

Figure 3. Response surface graph of enzymatic angelwing clam meat hydrolysate for ACE inhibitory activity (\%) as a function of temperature $\left({ }^{\circ} \mathrm{C}\right)$ and $\mathrm{pH}$.

A quadratic trend was also reported on the effect of temperature and $\mathrm{pH}$ on whey protein hydrolysate $[28,42]$ where the ACE inhibitory activity decreased gradually as the temperature and $\mathrm{pH}$ increased until a minimum optimum point and later increased gradually. Moreover, for sour milk fermentation [43], the ACE inhibitory activity increased as temperature and $\mathrm{pH}$ increased until it reaches an optimum point and decrease gradually afterwards.

Figure 4 shows the response surface plot with interaction between $\mathrm{pH}$ and time. Based on figure 4, a bell shaped graph with an optimum level occurred at the highest hydrolysis time and moderate $\mathrm{pH}$. Hydrolysis time gave linear effect to ACE inhibitory. Longer hydrolysis time was necessary to produce the ACE inhibitory peptides to increase the ACE inhibitory activity [44]. After reaching the optimum level, the ACE inhibitory activity will decreased gradually with increasing in $\mathrm{pH}$. Benjakul and Morrisey [41] states that enzyme tends to undergo irreversible denaturation and loss of stability at high $\mathrm{pH}$.

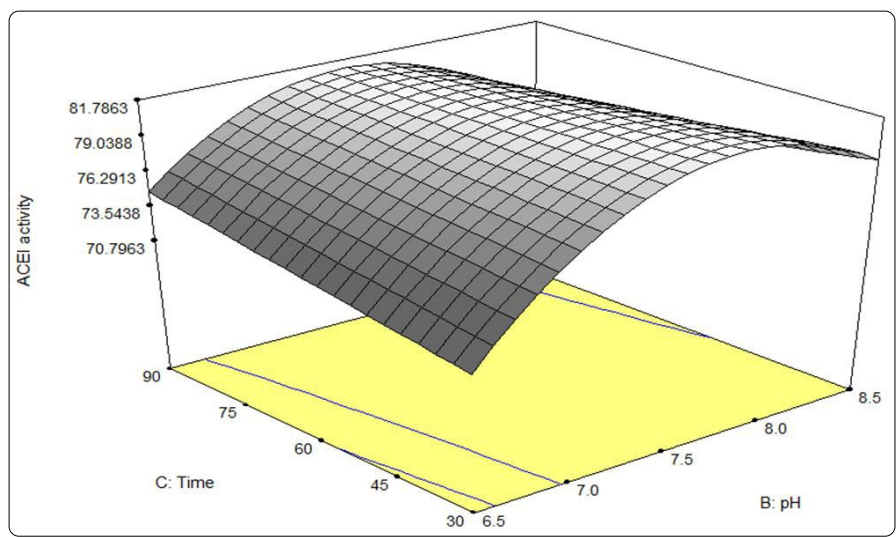

Figure 4. Response surface graph for ACE inhibitory activity (\%) as function of $\mathrm{pH}$ and hydrolysis time (minutes).
Figure 5 shows the response surface plot with interaction between hydrolysis time and enzyme concentration. ACE inhibitory was maximum at extreme ends. The optimal level was at the highest hydrolysis time but lowest enzyme concentration. However, ACE inhibitory activity decreased until minimum point at moderate conditions for both parameters and then increased gradually. Matsui et al. [45], reported that the hydrolysis time markedly affect the ACE inhibitory activity. Longer hydrolysis time produced higher ACE inhibitory activity. Nevertheless, increasing of enzyme concentration does not give any increase for ACE inhibitory activity after the maximum ACE inhibitory activity has achieved [24]. The graph shows that the lowest enzyme concentration possesses the highest ACE inhibitory activity.

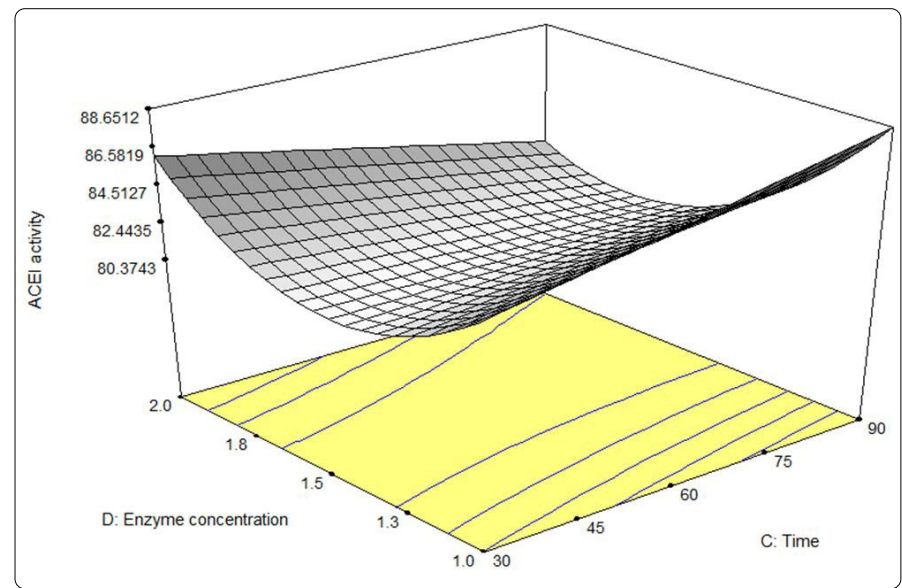

Figure 5. Response surface graph for ACE inhibitory activity as function of hydrolysis time (minutes) and enzyme concentration (\%).

Qu et al. [24] reported that different types of protein source have different dependability towards the hydrolysis time. Previous studies done on pacific hake fillet hydrolysate and marine microalgae $[32,46,47]$ where the ACE inhibitory activity increased gradually as the hydrolysis time increased. The ACE inhibitory activity decreased gradually once the optimum level had reached. Dadzie et al. [48] has similar situation with this study where the ACE inhibitory activity decreased with the temperature and enzyme concentration until minimum point and then it increased gradually.

\section{Optimization of ACE inhibitory activity}

Design Expert software will suggest optimum condition once the independent variable and dependent response were specified. All independent were set "in range" while the response variable was set as "maximum". The degree of importance differs between independent variables and dependent response variable with high number implies the high importance of the variable. The degrees of importance for independent variables were set to 3 , while the response variable was 5 . Following the setting, RSM had suggested several optimum conditions to hydrolysis anglewing clam protein producing maximum ACE inhibitory hydrolysate. Based on table 7, the selected suggested condition for this study was solution no 1 . The suggested conditions were at temperature of $54.8^{\circ} \mathrm{C}, \mathrm{pH}$ of $7.7,33$ minutes of and $1.0 \%$ enzyme concentration. The predicted ACE inhibitory activity was $85.2066 \%$ with the desirability of 1.000 . 
Table 7. Solutions for optimization conditions and maximum responses value

\begin{tabular}{|l|l|l|l|l|l|l|l|}
\hline No & Temperature & pH & $\begin{array}{l}\text { Hydrolysis } \\
\text { time }\end{array}$ & $\begin{array}{l}\text { Enzyme } \\
\text { concentration }\end{array}$ & $\begin{array}{l}\text { ACE } \\
\text { inhibitory } \\
\text { activity }\end{array}$ & Desirability & \\
\hline 1 & $\underline{54.8}$ & $\underline{7.7}$ & $\underline{33}$ & $\underline{1.0}$ & $\underline{85.2066}$ & 1.000 & Selected \\
\hline 2 & 54.4 & 7.4 & 88 & 1.0 & 87.8635 & 1.000 & \\
\hline 3 & 55.1 & 7.9 & 82 & 1.0 & 86.1406 & 1.000 & \\
\hline 4 & 54.3 & 7.7 & 43 & 2.0 & 85.4514 & 1.000 & \\
\hline 5 & 56.0 & 7.4 & 89 & 1.1 & 86.0738 & 1.000 & \\
\hline 6 & 55.5 & 7.6 & 36 & 2.0 & 85.7807 & 1.000 & \\
\hline 7 & 55.1 & 7.8 & 38 & 2.0 & 85.3869 & 1.000 & \\
\hline 8 & 53.6 & 7.2 & 85 & 1.1 & 85.6222 & 1.000 & \\
\hline 9 & 54.7 & 7.6 & 46 & 2.0 & 85.2052 & 1.000 & \\
\hline 10 & 55.4 & 7.2 & 85 & 1.0 & 86.7283 & 1.000 & \\
\hline
\end{tabular}

Verification of optimal conditions for ACE inhibitory activity

In order to validate the suggested mathematical model, four replicates of angelwing clam meat hydrolysis were conducted under the optimum conditions. The results of the replicates were $87.89 \%, 85.67 \%, 86.03 \%$ and $82.96 \%$ with the mean value of $85.64 \% \pm 2.03$. Statistical analysis using onesample t-test reveal that there was no significant different between the mean of experimental value and predicted value. The experimental value was close to $95 \%$ confident ( $p>0.05$ ). This indicates that the suggested mathematical model can be used as to predict the preparation of ACE inhibitory activity from the hydrolysis of angelwing clam meat using Alcalase ${ }^{\circledR}$.

Previous studies on validation on optimal conditions with experimental value of $72.8 \%$ from whey protein [29] $54.9 \%$ from alga [24], 76.68\% from probiotic in soy whey [49] and $85.27 \%$ from rice dreg [49]. This shows that different source of protein would yield different percentage of ACE inhibitory activity. Moreover, different range of parameters used and enzymes applied influenced to the differences value in ACE inhibitory activity.

\section{Half maximal inhibitory concentration $\left(\mathrm{IC}_{50}\right)$ of angelwing clam meat hydrolysate prepared under optimal conditions}

ACE inhibitory activity can also be expressed in $I_{50}$ value. $I C_{50}$ is defined as the concentration of protein inhibitor required to inhibit $50 \%$ of the ACE activity [50-52]. The $I C_{50}$ value obtained was $3.29 \mathrm{mg} / \mathrm{ml} \pm 0.481$. According to Qu et al. [23], stronger antihypertensive activity produced by the lower $\mathrm{IC}_{50}$. In this study, angelwing clam meat hydrolysate was higher compared to previous studies done on $I C_{50}$ from different protein source, which means that the antihypertensive activity of angelwing clam meat in this study was not very strong. Previous studies reported on $\mathrm{IC}_{50}$ were those of oyster protein with $0.49 \mathrm{mg} / \mathrm{ml}$ [53] salmon by products with 0.14 $\mathrm{mg} / \mathrm{ml}$ [21] hard clam with $0.027 \mathrm{mg} / \mathrm{ml}$ [54] and red snow crab shell with $0.471 \mathrm{mg} / \mathrm{ml}$ [54].

In addition, pure ACE inhibitory peptides with low molecular weight may also have lower $I C_{50}$ value compared to crude hydrolysate used in this study [5]. Cinq-Mars and LiChan [32] reported that the semi-pure peptides (fractionated) tend to obtain lower $I C_{50}$ than unfractionized peptides. Hence, angelwing clam meat hydrolysate may obtain a better ACE inhibitory activity if fractionization is carried out.

\section{Conclusion}

Model equation for hydrolysis of angelwing clam meat to obtain maximum ACE inhibitory activity can be predicted by using quadratic model with significant linear terms of $\mathrm{pH}(\mathrm{A})$ and temperature $(B)$, quadratic terms of time $\left(A^{2}\right)$, temperature $\left(B^{2}\right)$ and $\mathrm{E} / \mathrm{S}\left(\mathrm{D}^{2}\right)$ as well as $2 \mathrm{FI}$ terms of $\mathrm{pH}$-temperature $(\mathrm{AB})$ and time-E/S (CD). The optimum condition to yield maximum ACE inhibitory activity from angelwing clam meat hydrolysate were at temperature of $54.8^{\circ} \mathrm{C}$, pH of 7.7 , hydrolysis time of 33 minutes and enzyme concentration of $1 \%$. The experimental value obtained from the optimum condition (85.64\%) was close to the predicted value $(85.21 \%)$ and the $I_{50}$ of ACE inhibitory of angelwing clam meat hydrolysate was found to be at $3.63 \mathrm{mg} / \mathrm{ml}$.

\section{References}

1. Chalamaiah $M$, Dinesh Kumar B, Hemalatha $R$, Jyothirmayi T. Fish protein hydrolysates: proximate composition, amino acid composition antioxidant activities and applications: A review. Food Chem. 2012; 135(4): 3020-3038. doi: 10.1016/j.foodchem.2012.06.100

2. Hui YH. Handbook of Food Products Manufacturing: Health, Meat, Milk, Poultry, Seafood and Vegetables. New Jersey: John Wiley \& Sons; 2007.

3. Neklyudov AD, Ivankin AN, Berdutina AV. Properties and uses of protein hydrolysates (Review). Appl Biochem Microbiol. 2000; 36(5): 452-459. doi: 10.1007/BF02731888

4. Šližyte R, Daukšas E, Falch E, Storrø I, Rustad T. Yield and composition of different fractions obtained after enzymatic hydrolysis of cod (Gadus morhua) by-products. Process Biochem. 2005; 40(3-4): 1415-1424. doi: 10.1016/j.procbio.2004.06.033

5. Wu H, He HL, Chen $X L$, Sun $C Y$, Zhang $Y Z$, Zhou BC. Purification and Identification of Novel Angiotensin-I-Converting Enzyme Inhibitory Peptides from Shark Meat Hydrolysate. Process Biochemistry. 2008; 43(4): 457-61. doi: 10.1016/j.procbio.2008.01.018

6. Raghavan S, Kristinsson HG. ACE-inhibitory activity of tilapia protein hydrolysates. Food Chem. 2009; 117(4): 582-588. doi: 10.1016/j. foodchem.2009.04.058

7. Pfeffer MA. Angiotensin-converting enzyme inhibition in congestive heart failure: benefit and perspective. Am Heart J. 1993; 126(3 Pt 2):789793.

8. Alemán A, Giménez B, Montero $P$, Gómez-Guillén MC. Antioxidant activity of several marine skin gelatins. LWT - Food Sci Technol. 2011; 44(2): 407-413. doi: 10.1016/j.Iwt.2010.09.003

9. Actis GL, Ottaviani Jl, Fraga CG. Inhibition of angiotensin converting enzyme activity by flavanol-rich foods. J Agric Food Chem. 2006; 54(1): 229-234. doi: 10.1021/jf052263o

10. Lee JK, Jeon JK, Byun HG. Effect of angiotensin I converting enzyme inhibitory peptide purified from skate skin hydrolysate. Food Chem. 2011; 125(2): 495-499. doi: 10.1016/j.foodchem.2010.09.039

11. Amiza MA, Masitah M. Optimization of enzymatic hydrolysis of blood cockle (Anadara granosa) using Alcalase. Borneo Sci. 2012; 31: 1-8.

12. Ronquillo JD, Scott McKinley R. Developmental stages and potential mariculture for coastal rehabilitation of endangered Pacific angelwing clam, Pholas orientalis. Aquaculture. 2006; 256(1-4): 180-191. doi: 10.1016/j.aquaculture.2006.01.030

13. Normah I, Nurfazlika NMP. Evaluation on the Properties of Mentarang (Pholas orientalis) Protein Hydrolysate. Pertanika J Trop Agric Sci. 2013; 36(2): 199-210.

14. Normah I, Nurul Fasihah R. Bitterness and physichochemical properties of angle wing clam (Pholas orientalis) hydrolysate. Malaysian J Anal Sci. 2016; 20(3): 594-600.

15. AOAC. Official Method of Analysis. 17th ed. Washington: Association of 
Official Analytical Chemist. 2000

16. Hordur GK, Barbara AR. Kinetics of the hydrolysis of atlantic salmon (Salmo salar) muscle proteins by alkaline proteases and a visceral serine protease mixture. Process Biochem. 2000; 36(1-2): 131-139. doi: 10.1016/ S0032-9592(00)00195-3

17. Ko SC, Kang N, Kim EA, et al. A novel angiotensin I-converting enzyme (ACE) inhibitory peptide from a marine Chlorella ellipsoidea and its antihypertensive effect in spontaneously hypertensive rats. Process Biochem. 2012; 47(12): 2005-2011. doi: 10.1016/j.procbio.2012.07.015

18. Cushman DW, Cheung HS. Spectrophotometric assay and properties of the angiotensin-converting enzyme of rabbit lung. Biochem Pharmacol. 1971; 20: 1637-1648. doi: 10.1016/0006-2952(71)90292-9

19. Stansby ME. Proximate composition of fish. In: Heen E, Kreuzer R, eds. Fish in Nutrition. London: Fishing News (Books) Ltd.; 1962: 55-60.

20. Diniz FM, Martin AM. Effects of the Extent of Enzymatic Hydrolysis on Functional Properties of Shark Protein Hydrolysate. LWT - Food Sci Technol. 1997; 30(3): 266-272. doi: 10.1006/fstl.1996.0184

21. Ahn CB, Jeon YJ, Kim YT, Je JY. Angiotensin i converting enzyme (ACE) inhibitory peptides from salmon byproduct protein hydrolysate by Alcalase hydrolysis. Process Biochem. 2012; 47(12): 2240-2245. doi: 10.1016/j.procbio.2012.08.019

22. Saidi S, Belleville MP, Deratani A, Amar RB. Optimization of peptide production by enzymatic hydrolysis of tuna dark muscle by-product using commercial proteases. African J Biotechnol. 2013; 12(13): 15331547.

23. Qu W, Ma H, Pan Z, Luo L, Wang Z, He R. Preparation and antihypertensive activity of peptides from Porphyra yezoensis. Food Chem. 2010; 123(1): 14-20. doi: 10.1016/j.foodchem.2010.03.091

24. Aspmo SI, Horn SJ, Eijsink VGH. Hydrolysates from Atlantic cod (Gadus morhua L.) viscera as components of microbial growth media. Process Biochem. 2005; 40(12): 3714-3722. doi: 10.1016/j.procbio.2005.05.004

25. Bhaskar N, Mahendrakar NS. Protein hydrolysate from visceral waste proteins of Catla (Catla catla): optimization of hydrolysis conditions for a commercial neutral protease. Bioresour Technol. 2008; 99(10): 41054111. doi: 10.1016/j.biortech.2007.09.006

26. Chen J, Liu S, Ye R, Cai G, Ji B, Wu Y. Angiotensin-I converting enzyme (ACE) inhibitory tripeptides from rice protein hydrolysate: Purification and characterization. J Funct Foods. 2013; 5(4): 1684-1692. doi: 10.1016/j. jff.2013.07.013

27. Bougatef A, Nedjar AN, Ravallec PR, et al. Angiotensin I-converting enzyme (ACE) inhibitory activities of sardinelle (Sardinella aurita) byproducts protein hydrolysates obtained by treatment with microbial and visceral fish serine proteases. Food Chem. 2008; 111(2): 350-356. doi: 10.1016/j.foodchem.2008.03.074

28. Guo Y, Pan D, Tanokura M. Optimisation of hydrolysis conditions for the production of the angiotensin-I converting enzyme (ACE) inhibitory peptides from whey protein using response surface methodology. Food Chem. 2009; 114(1): 328-333. doi: 10.1016/j.foodchem.2008.09.041

29. Uluko H, Li H, Cui W, et al. Response surface optimization of angiotensin converting enzyme inhibition of milk protein concentrate hydrolysates in vitro after ultrasound pretreatment. Innov Food Sci Emerg Technol. 2013; 20: 133-139. doi: 10.1016/j.ifset.2013.08.012

30. Montgomery D. 11-4 Experimental Designs for Fitting Response Surfaces. InDesign and analysis of experiments. In: Design and Analysis of Experiments. 5th ed. New York: Wiley; 2001; 455.

31. Myers RH, Montgomery DC, Anderson CC. Response Surface Methodology: Process and Product Optimization Using Designed Experiments . Wiley Ser Probab Stat. 2009; 704. doi: 10.2307/1270613

32. Cinq MCD, Li CECY. Optimizing angiotensin I-converting enzyme inhibitory activity of pacific hake (Merluccius productus) fillet hydrolysate using response surface methodology and ultrafiltration. J Agric Food Chem. 2007; 55(23): 9380-9388. doi: 10.1021/jf0713354

33. Taheri A, Abedian KA, Motamedzadegan A, Rezaie MH. Optimization of goldstripe sardine (Sardinella gibbosa) protein hydrolysate using
Alcalase $^{\circledR} 2.4 \mathrm{~L}$ by response surface methodology. J Food. 2011; 9(2): 114-120. doi: 10.1080/19476337.2010.484551

34. Prabha J, Narikimelli AS,Vincent MIS. Optimization for autolysis assisted produc tion of fish protein hydrolysate from underutilized fish Pellona dit chela. Int J Sci Eng Res. 2013; 4(12): 1863-1869.

35. Mohammad AW, Kumar AG, Basha RK. Optimization of enzymatic hydrolysis of tilapia (Oreochromis Spp.) scale gelatine. Int Aquat Res. 2015; 7(1): 27-39. doi: 10.1007/s40071-014-0090-6

36. Sowmya R, Ravikumar TM, Vivek R, Rathinaraj K, Sachindra NM Optimization of enzymatic hydrolysis of shrimp waste for recovery of antioxidant activity rich protein isolate. J Food Sci Technol. 2012; 51(11): 3199-3207. doi: 10.1007/s13197-012-0815-8

37. Liu L, Wang Y, Peng C, Wang J. Optimization of the preparation of fish protein anti-obesity hydrolysates using response surface methodology. Int J Mol Sci. 2013; 14(2): 3124-3139. doi: 10.3390/ijms14023124

38. Noordin M, Venkatesh V, Sharif S, Elting S, Abdullah A. Application of response surface methodology in describing the performance of coated carbide tools when turning AISI 1045 steel. J Mater Process Technol. 2004; 145(1): 46-58. doi: 10.1016/S0924-0136(03)00861-6

39. Zou P, Wang JL, He GQ, Wu J. Purification, identification, and in vivo activity of angiotensin I-converting enzyme inhibitory peptide, from ribbonfish (Trichiurus haumela) backbone. J Food Sci. 2014; 79(1). C1-C7. doi: 10.1111/1750-3841.12269

40. Benjakul S, Morrissey MT. Protein Hydrolysates from Pacific Whiting Solid Wastes. J Agric Food Chem. 1997; 45(9): 3423-3430. doi: 10.1021/ jf970294g

41. Nelson D. Lehninger Principles of Biochemistry. New York: Amazon; 2005.

42. van der Ven $C$, Gruppen $H$, de Bont DBA, Voragen AGJ. Optimisation of the angiotensin converting enzyme inhibition by whey protein hydrolysates using response surface methodology. Int Dairy J. 2002; 12(10): 813-820. doi: 10.1016/S0958-6946(02)00077-8

43. Pan D, Guo Y. Optimization of sour milk fermentation for the production of ACE-inhibitory peptides and purification of a novel peptide from whey protein hydrolysate. Int Dairy J. 2010; 20(7): 472-479. doi: 10.1016/j.idairyj.2010.01.007

44. Otte J, Shalaby SM, Zakora M, Pripp AH, El-Shabrawy SA. Angiotensinconverting enzyme inhibitory activity of milk protein hydrolysates: Effect of substrate, enzyme and time of hydrolysis. Int Dairy J. 2007; 17(5): 488-503. doi: 10.1016/j.idairyj.2006.05.011

45. Matsui T, Matsufuji $H$, Seki E, Osajima K, Nakashima M, Osajima $Y$. Inhibition of angiotensin I-converting enzyme by Bacillus licheniformis alkaline protease hydrolyzates derived from sardine muscle. Biosci Biotechnol Biochem. 1993; 57(6): 922-925. doi: 10.1271/bbb.57.922

46. Wu H, Liu Y, Guo M, Xie J, Jiang X. A Virtual Screening Method for Inhibitory Peptides of Angiotensin I-Converting Enzyme. J Food Sci. 2014; 79(9): 1635-1642. doi: 10.1111/1750-3841.12559

47. Dadzie RG, Ma H, Abano EE, Qu W, Mao S. Optimization of process conditions for production of angiotensin I-converting enzyme (ACE) inhibitory peptides from vital wheat gluten using response surface methodology. Food Sci Biotechnol. 2013; 22(6): 1531-37. doi: 10.1007/ s10068-013-0248-9

48. Fung WY, Liong MT. Evaluation of proteolytic and ACE-inhibitory activity of Lactobacillus acidophilus in soy whey growth medium via response surface methodology. LWT - Food Sci Technol. 2010; 43(3): 563-567. doi: 10.1016/j.lwt.2009.10.004

49. He G, Xuan G, Ruan $H$, Chen Q, Xu Y. Optimization of angiotensin I-converting enzyme (ACE) inhibition by rice dregs hydrolysates using response surface methodology. J Zhejiang Univ Sci B. 2005; 6(6): 508513. doi: 10.1631/jzus.2005.B0508

50. Donkor ON, Henriksson A, Singh TK, Vasiljevic T, Shah NP. ACE-inhibitory activity of probiotic yoghurt. Int Dairy J. 2007; 17(11): 1321-1331. doi: 10.1016/j.idairyj.2007.02.009

51. Lee SH, Qian ZJ, Kim SK. A novel angiotensin I converting enzyme 
inhibitory peptide from tuna frame protein hydrolysate and its antihypertensive effect in spontaneously hypertensive rats. Food Chem. 2010; 118(1): 96-102. doi: 10.1016/j.foodchem.2009.04.086

52. Wang J, Hu J, Cui J, et al. Purification and identification of a ACE inhibitory peptide from oyster proteins hydrolysate and the antihypertensive effect of hydrolysate in spontaneously hypertensive rats. Food Chem. 2008; 111(2): 302-308. doi: 10.1016/j.foodchem.2008.03.059

53. Tsai JS, Chen JL, Pan BS. ACE-inhibitory peptides identified from the muscle protein hydrolysate of hard clam (Meretrix lusoria). Process Biochem. 2008; 43(7): 743-747. doi: 10.1016/j.procbio.2008.02.019

54. Yoon NY, Shim KB, Lim CW, Kim SB. Antioxidant and Angiotensin I Converting Enzyme Inhibitory Activities of Red Snow Crab Chionoecetes japonicas Shell Hydrolysate by Enzymatic Hydrolysis. Fish Aquat Sci. 2013; 16(4): 237-242. doi: 10.5657/FAS.2013.0237 